The Challenge of British Management 


\section{ECONOMICS TODAY \\ Edited by Andrew Leake}

The Economics Today series surveys contemporary headline topics in applied economics. Each book in the series is written by an expert in the field in a style that is fluently readable. It serves the student of introductory economic principles while also making the subject accessible to a more general reader. The series embraces the problem-solving skills of the new generation of students and stresses the importance of real-world issues and the significance of economic ideas.

\section{Published}

Andrew Leake: The Economic Question

Jean-Louis Barsoux and Peter Lawrence: The Challenge of British Management

S. F. Goodman: The European Community

Jenny Wales: Investigating Social Issues

\section{Forthcoming}

\section{Frank Burchill: Labour Relations}

\section{Series Standing Order}

If you would like to receive future titles in this series as they are published, you can make use of our standing order facility. To place a standing order please contact your bookseller or, in case of difficulty, write to us at the address below with your name and address and the name of the series. Please state with which title you wish to begin your standing order. (If you live outside the UK we may not have the rights for your area, in which case we will forward your order to the publisher concerned.)

Standing Order Service, Macmillan Distribution Ltd, Houndmills, Basingstoke, Hampshire, RG21 2XS, England. 


\title{
THE CHALLENGE OF BRITISH
}

MANAGEMENT

\author{
Jean-Louis Barsoux \\ and \\ Peter Lawrence
}

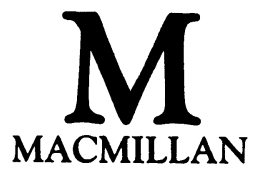


All rights reserved. No reproduction, copy or transmission of this publication may be made without written permission.

No paragraph of this publication may be reproduced, copied or transmitted save with written permission or in accordance with the provisions of the Copyright, Designs and Patents Act 1988 , or under the terms of any licence permitting limited copying issued by the Copyright Licensing Agency, 33-4 Alfred Place, London WC1E 7DP.

Any person who does any unauthorised act in relation to this publication may be liable to criminal prosecution and civil claims for damages.

First published 1990

Published by

MACMILLAN EDUCATION LTD

Houndmills, Basingstoke, Hampshire RG21 2XS

and London

Companies and representatives

throughout the world

Typeset by Latimer Trend \& Company Ltd

Plymouth

British Library Cataloguing in Publication Data

Barsoux, Jean-Louis

The challenge of British management.

1. Great Britain. Management.

I. Title II. Lawrence, P. A. (Peter Anthony) 1937-

658.00941

ISBN 978-0-333-53486-1

ISBN 978-1-349-21047-3 (eBook)

DOI 10.1007/978-1-349-21047-3 
For my Grandparents

(Jean-Louis Barsoux)

\author{
For Mig \\ (Peter Lawrence)
}




\section{Contents}

Acknowledgements xi

Preface xii

1 What is Management? 1

A Working Definition 1

Consciousness creates Reality 2

Stocktaking 4

Where does Management Start? 5

In Industry or in Organisations 6

What Managers Do All Day 8

Truth Starts in Sweden 9

Brevity, Variety and Fragmentation

A British Study of Management Work 13

Variety Revisited 14

A Range of Issues 15

All Working for the Same Company 16

\section{The Chequerboard of Roles 19}

The House that Jack Built 20

A Star is Born 21

Between Conceiving and Making 22

End of the Trail? 22 
Production's Supporting Cast

Systematising People

29

Carry on Counting

31

A Window on the World

In Which We Serve 34

Plus ça Change? 35

Reconciling the Irreconcilable

Embarras de Choix

37

Interpretation at Work 38

Means to Ends 39

3 Management Process or How It's Done

Where are the Rules? 41

What will They Do if I Give them Orders?

What About the Workers? 45

Sideways to the Finishing Post

47

Gaining Power in the Organisation 51

Advocacy 53

Studying Process 53

Bias or Basis? 54

Why is the World Like This? 54

Where Do Our Managers Come From? 56

Improving by Degrees 57

A Shot in the Dark 57

Qualifying Standards 58

Surrogate Business Schools 59

The Lure of Accountancy 60

Dirty Hands and Empty Pockets 61

Functional Pecking Orders 62

From Milk Round to Gravy Train 64

Fast Trackers 64

Mentoring 65

Just Passing Through 67

Itchy Feet 68

Oh to be in England 69

A Breed Apart 71 


\section{Small is Beautiful 73}

The Rise of the Small Business 73

The Small Business Population $\mathbf{7 4}$

Government Support 75

The Biggest Hurdle 76

The Credibility Gap 79

Doing it Without Money 79

Reaching a Market 82

The Market Niche Idea 83

Coming of Age 85

Does Size Matter? 86

Make or Break 88

\section{Sales Pitch 90}

Retail is Detail 91

A Very British Success

Sparks Fly 94

Overseas Selling 95

Fraternal Twins 95

Getting Round Foreign Customs 97

Pardon my French $\quad 100$

Tongue-tied $\quad 100$

Marketing Revisited 102

Ambidextrous Companies 103

7 Is There a British Management Style? 106

National Style 108

Jack of all Trades 108

Informality Rules 109

Funny Business 111

The Persuaders 113

Muddling Through? 115

Management in Society 117

Over Space and Time 119

8 British Corporate Success 122

Free for All 123

Hands-on or Arm's-length? 
X Contents

A Light Grip around the Throat 126

Corporate Strategy 128

Plan or be Damned 131

Banking on the Future 133

Fortune's Wheel 133

Hooked on Drugs 135

Corporate Culture 136

The Way We Do Things 137

\section{Q Challenge, What Challenge? 139}

Tour des Forces 139

A Weakness for British Management 143

Challenges 146

Notes and References $\quad 150$

Index 155 


\section{Acknowledgements}

We would both like to thank all the companies that have extended their hospitality to us, and the many managers who have been kind enough to talk to us about their work.

JEAN-LOUIS BARSOUX

Peter LAWRENCE

Note

Portions of this book were previously published under the title Invitation to Management (Basil Blackwell, Oxford, 1986), singly authored by Peter Lawrence. 


\section{Preface}

The present book responds in fact to a variety of challenges. Some of the confusion surrounding management derives from the possibility of viewing management variously as an idea, a subject, and an activity: we have tried to dispel the confusion. Much of what managers do is somewhat opaque to the general public: we have tried to describe management work honestly. There is some doubt as to whether all management work is the same or whether it differs markedly from job to job: we have tried to elucidate both the patterns and the variation. The more formal textbooks are not always very clear about how managers actually get things done: we have tried to illuminate these processes.

Having tried to lay these foundations for an understanding of management in general and cosmopolitan terms, we shift the focus on to Britain. Here we look at management training and qualifications, development and careers, business start-ups and small companies, and at various forms of selling - home market, retail and export. We attempt a delineation of British management style, using our knowledge of management in several other countries to say what is definitive and expressly British about the way managers in this country approach their work. We follow this by looking at some of Britain's corporate successes, and offer reflections on the dynamics of this success. We round off with some thoughts on how British management has changed in the later twentieth century, what it does well, and where gains may be made. 